Article

\title{
Housing-Based Urban Planning? Sir Patrick Geddes' Modern Masterplan for Tel Aviv, 1925
}

\author{
Yael Allweil * and Noa Zemer \\ Faculty of Architecture and Town Planning, Technion-Israel Institute of Technology, Haifa 3200003, Israel; \\ E-Mails: allweil@ar.technion.ac.il (Y.A.), noa.zemer@campus.technion.ac.il (N.Z.) \\ * Corresponding author
}

Submitted: 7 April 2019 | Accepted: 29 July 2019 | Published: 30 September 2019

\begin{abstract}
This article studies Sir Patrick Geddes' housing-based urban planning, pointing to a less-explored aspect of his groundbreaking work, while proposing ways to rethink the history and theory of modern urban planning towards a "housing builds cities" planning agenda. Focusing on Geddes' modern urban planning for Tel Aviv in 1925 as housing-based urbanism, this article conceives urban structure and urban housing as one single problem rather than disconnected realms of planning. Based on new findings and revised study of available sources, we look into three planning processes by which policy makers, planners, and dwellers in Tel Aviv engaged in this housing-based urban vision: (1) The city as a housing problem; (2) the city as social utility for reform and reconstruction; and (3) housing-based urbanization as self-help. We show how Geddes' modern urban plan for Tel Aviv employed the city's pressing housing needs for urban workers to provoke planning by way of cooperative neighborhoods based on self-help dwellings. This approach was grounded on Geddes' survey of Tel Aviv's early premise on housing and extends beyond Geddes' period to the brutalist housing estates of the 1950 s and 1960s. The result is a new historiographic perspective on Tel Aviv's UNESCO-declared modern urbanism vis-à-vis housing as the cell unit for urban living. Further, insights regarding Tel Aviv's housing-based planning are relevant beyond this city to other examples of the town planning movement. It proposes rethinking modern urban planning before the consolidation of CIAM (Congrès Internationaux d'Architecture Moderne) principles, namely when planned settlements were explicitly experimental and involved diverse processes, scales, methods, practices and agents. Housing -a key arena for the modernization of the discipline of architecture, as well as for the consolidation of the discipline of urban planning-is studied here as the intersection of sociopolitical, formal, aesthetic, and structural elements of the city.
\end{abstract}

\section{Keywords}

city planning; Garden City; housing; modern planning; Patrick Geddes; Tel Aviv; urban theory; urban workers

\section{Issue}

This article is part of the issue "Housing Builds Cities", edited by Luca Ortelli (École Polytechnique Fédérale de Lausanne, Switzerland), Chiara Monterumisi (École Polytechnique Fédérale de Lausanne, Switzerland) and Alessandro Porotto (École Polytechnique Fédérale de Lausanne, Switzerland).

(C) 2019 by the authors; licensee Cogitatio (Lisbon, Portugal). This article is licensed under a Creative Commons Attribution 4.0 International License (CC BY).

\section{Introduction}

This article discusses Geddes' urbanism beyond regional planning. It examines Geddes' less-discussed idea of a housing-based city, built by its own dwellers based on semi-autonomous urban blocks. We focus on Tel Aviv's urban history as a manifestation of Geddes' housing- based urban theory to rethink the role of housing in shaping cities, and the ways in which housing "builds" cities. Housing-based urbanism is Geddes' less-studied idea. Scholarship about Geddes' urbanism focuses primarily on his anarchist notion of regional planning forming free confederations of autonomous regions-as opposed to planning the giant metropolis, the nation and 
the empire, and developing methods of detailed specific survey of built environments and populations (Hall, 1988; Meller, 1990). Geddes' ideas were influenced by French geographers Reclus and de la Blanch, and by sociologist Le Play-whom he met with at the Paris Exhibition of 1878-and spread as far as Hong Kong and America to influence the formation of regional cities like Sunnyside Gardens and Radburn (Allweil, 2016; Law, 2005; Meller, 1995). Even so, his ideas were overarchingly not executed, not even by his most well-known successors Mumford and Abercrombie (Hall, 1988; Mumford, 1925; Tyrwhitt, 1949).

In order to explore the development of this nonconventional idea and its evolution in Geddes' work across time and space, we examined his archive, published writing and many planning reports. Archival research of Geddes' Archive at the Strathclyde University includes historical photographs, drawings, plans and pamphlets starting with his work in Edinburgh, and panels of his celebrated travelling Cities Exhibition (Figures 1, 2 and 3). These archival findings, as well as Geddes' published work and many planning reports for cities and neighborhoods for communities across the British Empire, attest to housing as the starting point in Geddes' planning theory, survey method, and urban plans.

The revolutionary idea of housing-based urbanism underlies Geddes' 1925 masterplan for Tel Aviv-his only work ever realized. Geddes' plan was based on a detailed survey of the town as housing estate and accepted Tel Aviv's use of housing as building block to produce a "Housing Before Street" urban planning. This plan for Tel Aviv as a city of 100,000 people was the cornerstone of three planning processes that characterize Tel Aviv's urban history as a 'housing before street' urban development process. This planning approach defines housing as the building block for cities to the city's post-war development by way of brutalist housing estates. Geddes' plan, still in effect, was the city's only approved overarching masterplan until the masterplan TA5000 of 2016, its urban planning and urban design principles consolidating and determining the city's urban foundations. Yet, its housing-based principle is still largely understudied.

Geddes' Tel Aviv plan poses an alternative to accepted models of modern planning: technocratic-capitalist Haussmanism, aesthetic City Beautiful, Corbusian "radiant cities", or utopian Garden City (Hall, 1988). At the same time, contrary to the phenomenon of makeshift housing predating formal settlement and creating the city de-facto-as in the auto-constructed peripheries of Cairo, Brasilia or Calcutta-Tel Aviv's formation via housing was the result of a conscious planning process where Geddes fully realized his ideas: not merely challenging top-down mechanisms but disrupting the very dichotomous perspective of modern urbanism as a clash between top-down planner-ideologues and bottom-up urban citizens (Allweil, 2016). Moreover, Geddes' planning principle has been dominant in the city ever since, reflected in the city's post-war development of brutal- ist housing estates into large neighborhoods and segments of the city (Hoffmann \& Nevo-Goldberst, 2017; Marom, 2009).

This article focuses on three planning processes by which policy makers, planners, and dwellers in Tel Aviv engaged in this housing-based urban vision: (1) The city as a housing problem; (2) the city as social utility for reform and reconstruction; and (3) urbanization as act of self-help.

\section{Methodology}

The methods applied in this research are predominantly the methods of architectural and urban history, namely archival research of architectural and planning documents, historical photographs, and analysis of planning reports. The archives studies include the Geddes Archive at University of Strathclyde Special Collection, Tel Aviv City Archive, Tel Aviv Technical Archive, and David Azrieli Archive of Israeli Architecture. In addition, our inquiry included identifying historical elements in the built environment, site documentation, and architectural reading of plans and facades.

\section{The City as a Housing Problem}

Since Geddes' interest in urbanism revolved around his conception of housing as the building block for cities, his approach to urban planning involved seeing housing and urbanism as one single problem. A founding member of the city planning movement, Geddes was nonetheless marginal to the movement for his challenge of the very idea that new cities form due to the powerful actions of statesmen, capitalists, and planners (Law, 2005; Rubin, 2009). Like many Garden City planners, issues of housing in the industrial city affected Geddes' urban vision. Yet compared with other theorists of urban planning, Geddes insisted that:

Urban Planning cannot be made from above using general principles...studied in one place and imitated elsewhere. City planning is the development of a local way of life, regional character, civic spirit, unique personality...based on its own foundations. (Geddes, 1915 , p. 205)

At Edinburgh's Old Town Tenements, Geddes developed his famous method of the survey. Based on a three dimensional aerial drawing, Geddes traced simple logical connections regarding the built environment; overcrowding and under-housing, with high rents and high land values, result from the restrictive defensive walls of the medieval city, while the notorious filth, from poor water supply, in turn comes from its hill site (Leonard, 1999; see Figure 1). Geddes' valley section was imbued with Le Play's trinity of Lieu, Travail, Famille, stressing the family as the basic social unit in the context of its environment (Meller, 1990, p. 35). For Geddes: 


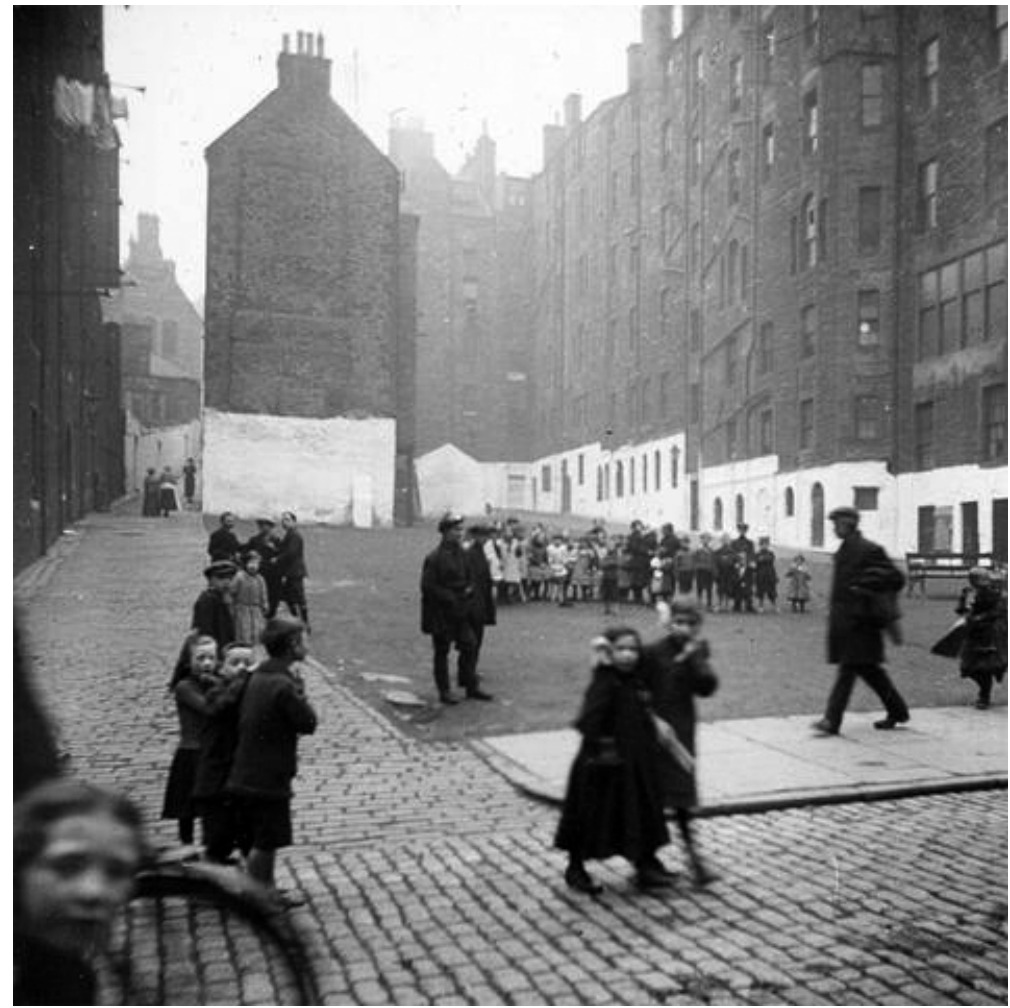

Figure 1. Edinburgh Old Town Tenements, 1911, by Patrick Geddes. Source: Patrick Geddes Papers (n.d.).

The natural eugenic center is in every home; its young go out to make new homes; these make the village, the town, the city small or great....Federate homes into co-operative and helpful neighborhoods. Unite these grouped homes into renewed and socialized quarters... and in time you have a better nation, a better world. (Geddes, as cited in Defries, 1927, pp. 218-219)

Peter Hall termed Geddes' important contribution to planning theory the "city of sweat equity" approach to urban housing, proposing that men and women could make their own cities (Hall, 1988). Having himself lived in a tenement in Edinburgh in the 1880s, "taking a very poor flat among the workers", Geddes' outlook was deeply affected by issues of housing in the industrial city (Kropotkin, as cited in Boardman, 1978, p. 87). For Geddes, the problem of slum housing was scientific on one hand and self-organizational on the other. Geddes recounts:

Facing and tackling of dirt and overcrowding and disorder of even more infernal slumdom than now exists in Edinburgh; and to begin such changes as might be, thus became problems as scientific, as technical, as had been those of living nature and its science. (Geddes, as cited in Boardman, 1978, pp. 86-87)

In order to improve these conditions, the tenants started "within...limited range, with flower-boxes for dull windows and color-washing for even duller walls...we soon got to fuller clearings and repairings, next even to renewals, at length to building" (Geddes, as cited in Boardman, 1978, pp. 86-87; see Figure 2). Yet Geddes did not limit himself to tenement repairing. He soon started thinking about alternatives for the tenement as the dwelling solution for urban workers, gravitating from social reform to urban planning.

Geddes' archive at the University of Strathclyde includes a large collection of plans for worker housing that depart from the tenement type (part of his 1918 Cities Exhibition). These indicate that his explorations of city planning were not limited to regional planning and repairing of public space, but rather invested great effort in exploring worker house types as the building block for cities (Figure 3). This attention to detailed house design points to Geddes' transition from urban design repairs to urban planning based on typological explorations of houses and urban blocks. In his masterplan for the city of Indore, Geddes explored worker housing as an architecturally-designed unit, his planning report including drawings for potential house types and their groupings into urban blocks (Figure 4). Geddes' celebrated proposal for Indore identified housing for poor workers as the element structuring the urban block, proposing houses to be self-constructed by the city's urban workers, and expanded on over time (Geddes, 1918; see Figure 5).

In 1925, Geddes was invited to attend the opening ceremony for the Hebrew University. Tel Aviv's mayor Dizengoff took the opportunity and approached Geddes for designing a masterplan for the city's development (Rubin, 2009). Then, Tel Aviv found itself at a major cross- 


\section{COGITATIO}
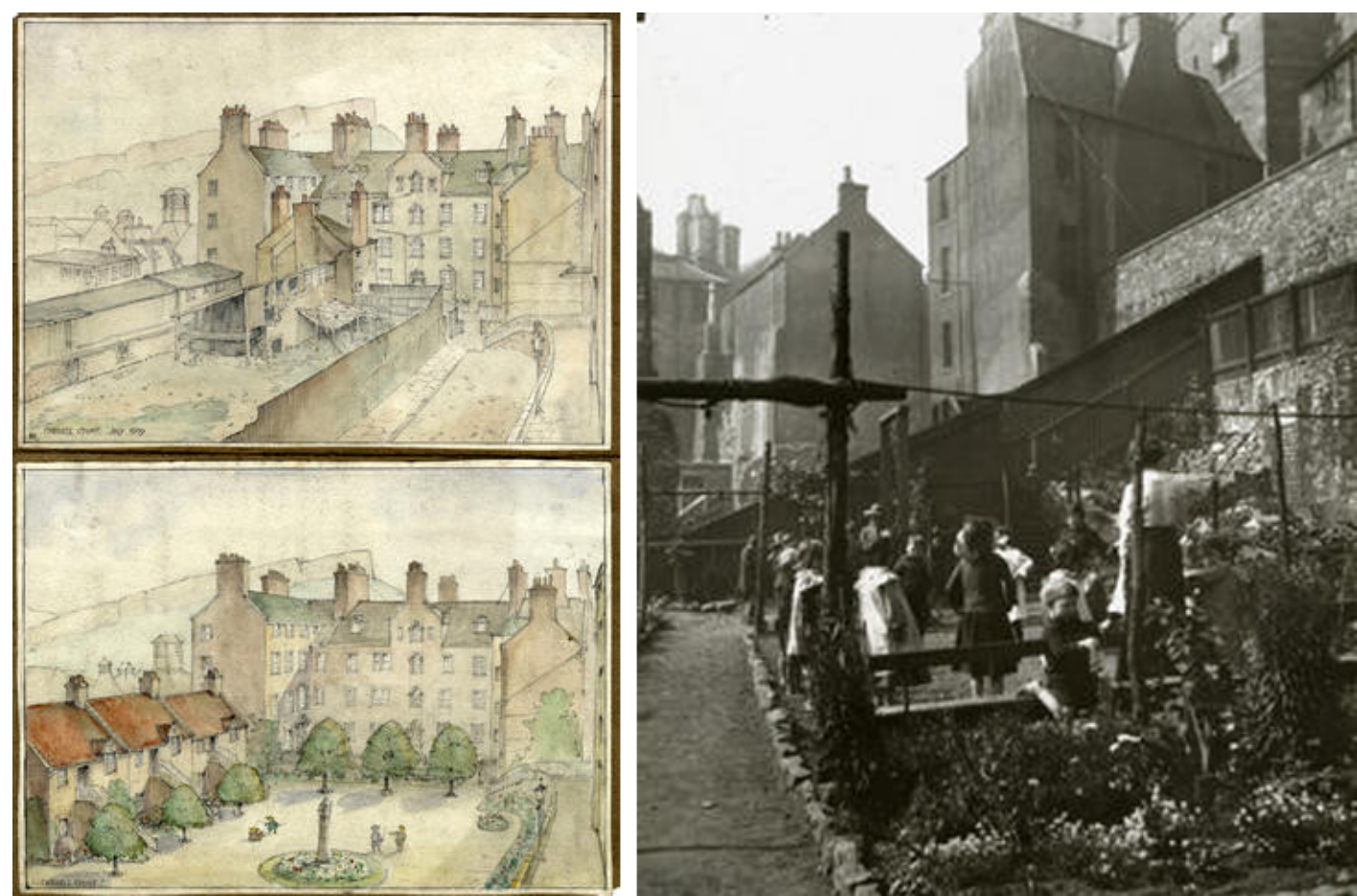

Figure 2. Repairings of Edinburgh Old Town Tenements, 1911. Photograph by Patrick Geddes and drawings by Nora Mears. Source: Patrick Geddes Papers (n.d.).

road: its population quadrupled in the four years following the transition from Ottoman to British rule and the beginning of ethnic-national clashes in Palestine in the 1920s, which generated mass urban migration and the formation of tenements and substandard housing
(Biger \& Shavit, 2001; Marom, 2009). The town was submerged by the sudden mass construction of tents and shacks filling every undeveloped tract, transforming the town into a crowded agglomeration of neighborhoods with no clear structure. Rising land prices
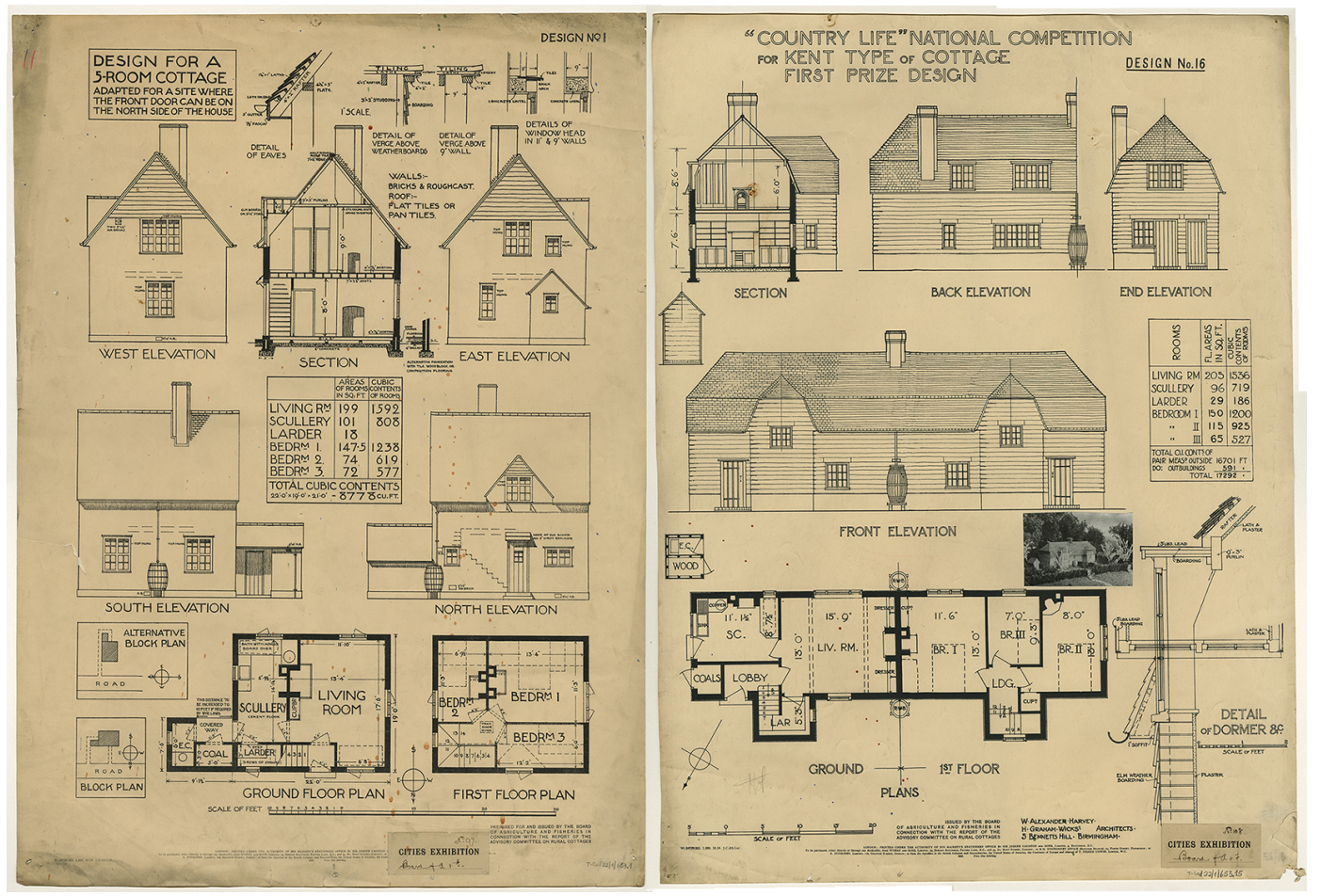

Figure 3. House type drawings by the Board of Agriculture and Fisheries, in connection with the Report of the Advisory Committee on Rural Cottages. Source: Patrick Geddes Papers (n.d.). 


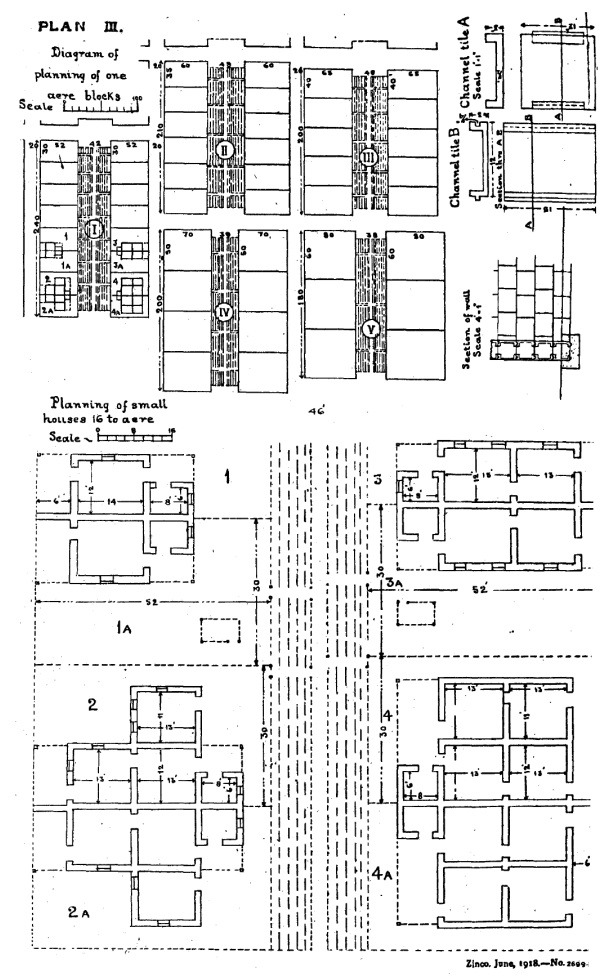

Figure 4. Indore expanding worker housing proposal. Source: Geddes (1918).

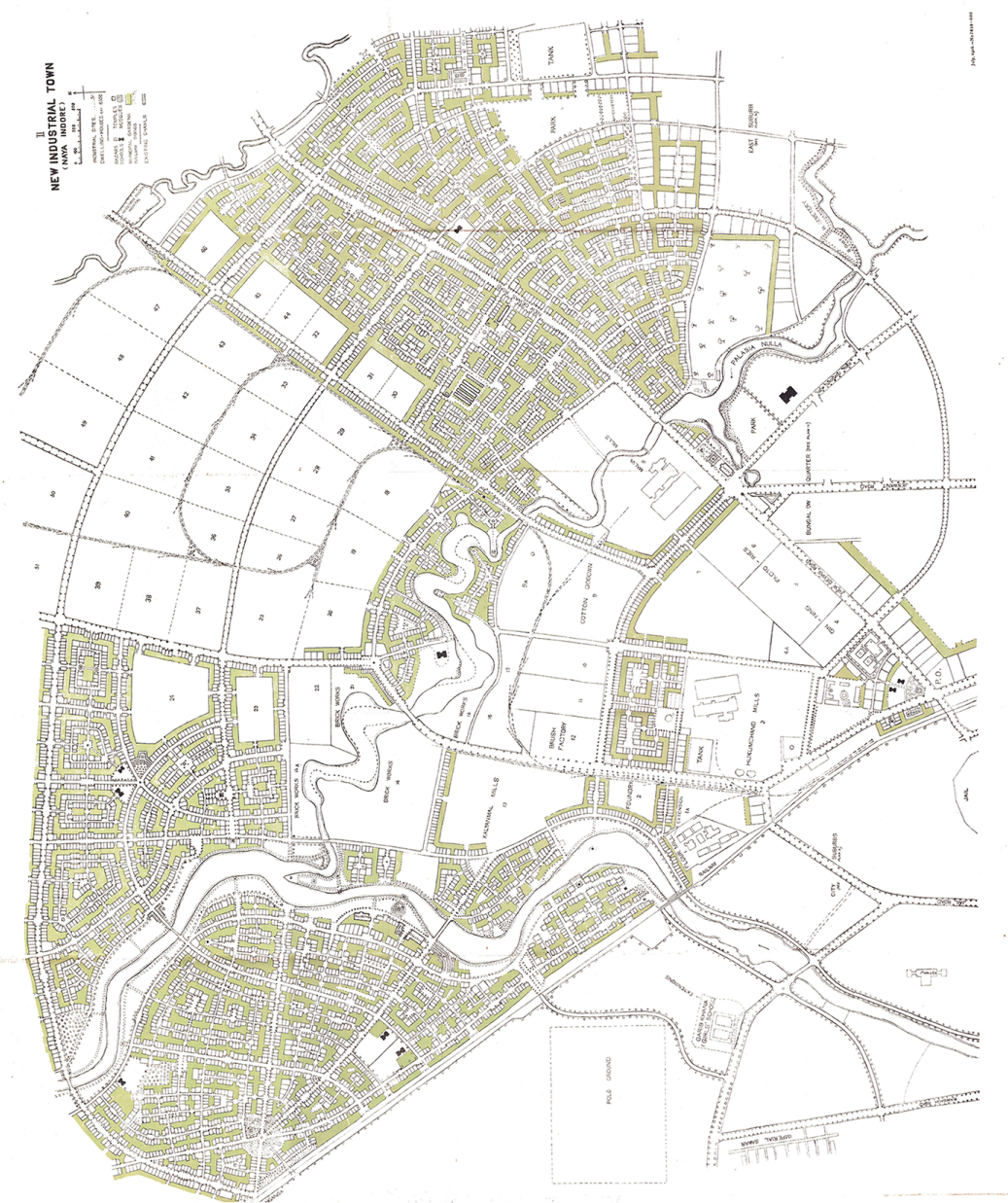

Figure 5. Indore urban block explorations. Source: Geddes (1918). 
led to overcrowding, with disregard for construction regulations. These dwellings had no running water or sewage, no streets, electricity or social services. Shack neighborhoods changed Tel Aviv from a homeowner community to one composed of a large population of poor renters and self-constructed shacks (Allweil, 2017). All this bore drastic political consequences and threatened Mayor Dizengoff's domination of urban politics. Dizengoff tried to meet this challenge with urban planning (Marom, 2009).

Geddes spent two months surveying the city and region and produced a 64-page town planning report and a plan for Tel Aviv as a city for 100,000 inhabitants which he defined as his most ambitious plan (Geddes, 1925; Weill-Rochant, 2008). In his report Geddes addresses Tel Aviv in its region, including a survey of Jaffa. Yet Geddes' clients aspired to employ modern city planning in order to distance Tel Aviv from Jaffa. Geopolitical conflicts between Jews and Arabs, the transition to British rule, and landownership by Western settlers confined the plan to the south and east, and its home-block orientations (Marom, 2009; Rubin, 2009).

The focus of Geddes' survey was Tel Aviv's housing condition, "at a crossroads between two types of housing development: its original detached cottages with small gardens-and tenement "human warehousing"' (Geddes, 1925, p. 13). Geddes presented this crossroad in his report by analyzing two nearby housing types in the Shapira alley: detached cottages with small gardens and a nearby warehousing tenement block. For Geddes, these two housing types "represent the essential contradiction between the two types of planning" (Geddes, 1925, p. 13; Figure 6). Tenements, Geddes declared, contributed to high mortality rates, especially in children. He therefore defined housing a moral issue, "a measure of good citizenship, for our care not only or mostly for our own lives but...for each other and the entire human beehive". Understanding housing as such, Geddes declared his planning purpose as "continu[ing] the Garden Village Tel Aviv began with and bettering this as far as may be" (Geddes, 1925, p. 15). The house plot in Geddes's report was 560 square meters, with construction area limited to one-third and building height to 9 meters, to contain a single, semi-detached house with no more than two residential units, leaving much of the plot for subsistence farm. The city's building block, the house, was the cell composing urban units, what Geddes termed the "home-block", structuring the city's large-scale urban scheme (Allweil, 2017; Geddes, 1925). Geddes' proposal for worker housing in Tel Aviv matches the type explorations identified at the Geddes archive, discussed above, and extend his proposals for house types and urban block types in earlier plans like Indore.

To provide an uncrowded dwelling environment, Geddes proposed a structured linear extension of the city northward to its municipal border on the Yarkon river, disregarding land ownership and the likelihood of immediate development. This was a long-term vision for

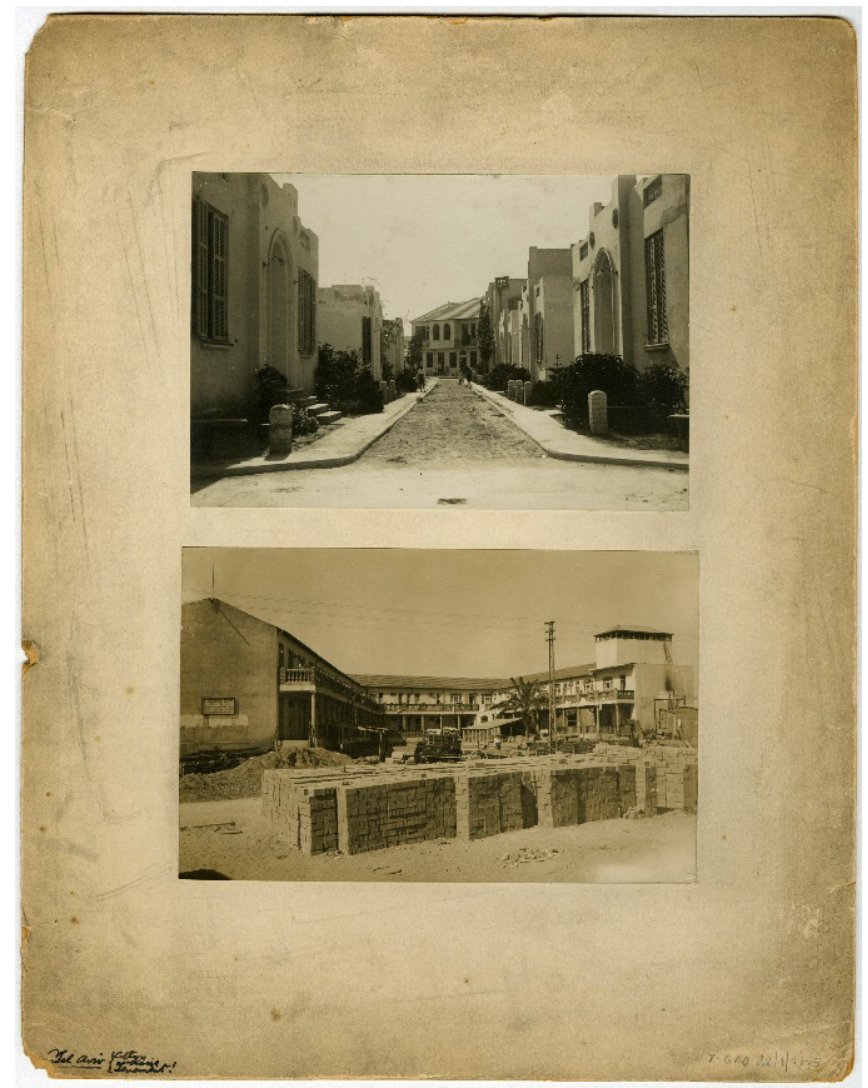

Figure 6. The Shapira Alley cottages versus nearby tenement (author unknown). Source: Patrick Geddes Papers (n.d.). 
urban development rather than the continuation of Tel Aviv's concentric development as a collection of neighborhoods around the city center. Geddes' urban structure for Tel Aviv laid down a non-orthogonal grid, based on the region's geography and existing routes and landmarks in the landscape. This made possible urban blocks of varied size and character within a unified urban structure for the city. The home-block idea had appeared in Geddes' work as early as his 1915 Cities in Evolution (Welter, 2009). Geddes examined cases of superblock design and made an active departure from the cul-de-sac blocks to the use of "homeways" that distinguished main from local roads yet kept inner-block parks and civil facil- ities as part of the city's civic system (Payton, 1996; see Figures 4 and 5). Geddes' explorations of the urban block in multiple planning schemes for cities in India, especially in his Indore plan discussed above, culminated in his Tel Aviv plan into well-articulated home-block urban units: urban blocks composed of two rings of detached houses, around the inner circumference and the outer circumference of the block. Each block included a small public park with communal facilities such as playgrounds and tennis courts. "Mainways" through traffic surround the homeblock. Narrow "homeways" and pedestrian ways lead to the inner block without traversing it (Geddes, 1925; Meller, 1990; see Figure 7).

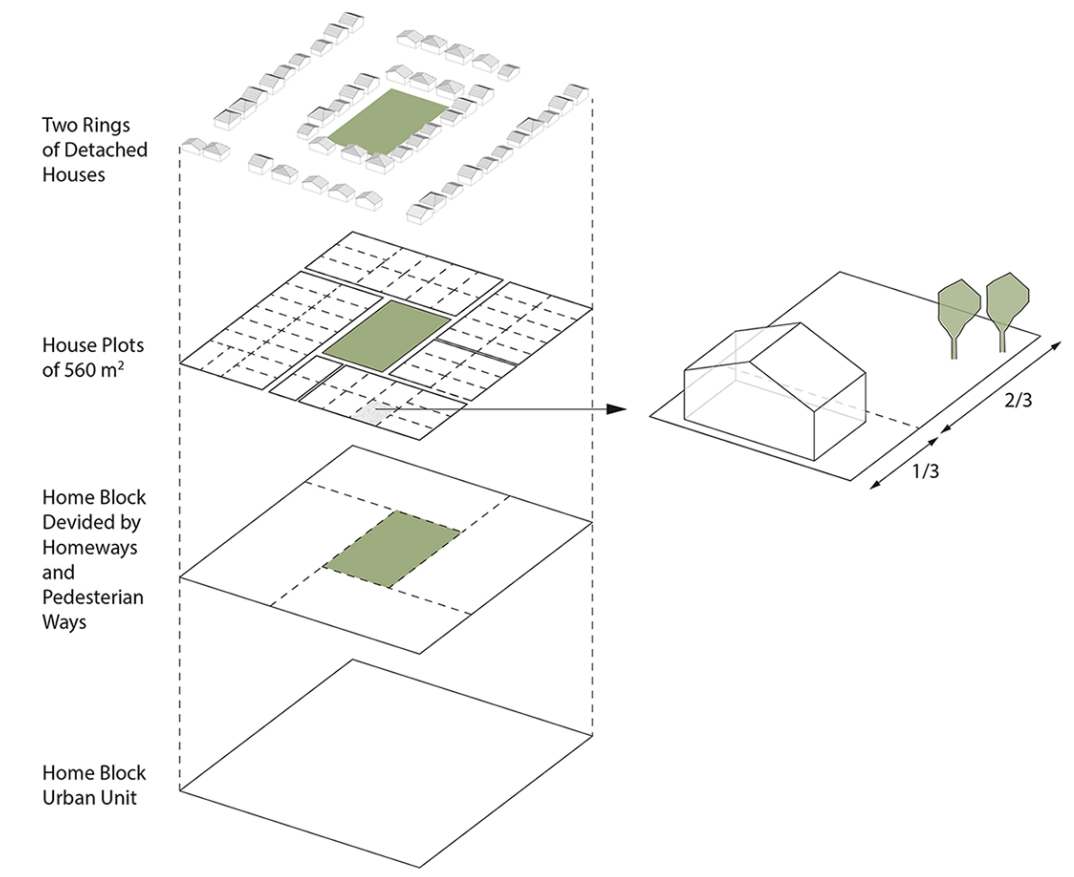

Figure 7. Block scheme after Geddes. Source: Authors. 
Geddes' town planning report was adopted into a masterplan whose recommendations were incorporated by the Technical Department of the Tel Aviv municipality and approved by the city council on 6 April 1926. In 1927, the Planning Board of the Mandatory Authority approved a legal document containing a colored map and written by-laws, drafted in accordance with the British Mandatory Town Planning Order of 1921 (Marom, 2009). Plan adaptation included a detailed street layout and parcel allotment plan, prepared by the engineers of the Tel Aviv's technical department (Weill-Rochant, 2008). Discussed primarily as urban layout, based on the assumption that Geddes' worker housing was never constructed (Meller, 1990; Weill-Rochant, 2003). Most of the research and discourse of Tel Aviv's worker housing revolves around the few well known Meonot Ovdim (worker residences) designed by Arie Sharon. Self-built "worker neighborhood" home-block dwellings all over the city were largely forgotten since they were not designed by architects (Greicer, 2017; Sharon, 1937).
However, findings uncovered in the archives and the built environment prove that Geddes' housing scheme was fully realized by the mid-1930s, its realization founded on worker housing via the sweat of the city's disenfranchised worker community. Unlike many other cities for which Geddes produced masterplans, Tel Aviv adopted his planning principles and specific design implemented into a statutory plan (see Figure 8).

The city as a housing problem and the concerns for Tel Aviv's housing-based urbanism carried over into the 1950s and 1960s. Israel's "first generation" architects critiqued CIAM (Congrès Internationaux d'Architecture Moderne) urban principles by adopting and appropriating the social values of European New Brutalism (Karmi, 2001; Shadar, 2014). Influenced by Team X, who in turn were influenced by Geddes, architects aimed to create viable communities related to their own culture and environment (Hoffmann \& Nevo-Goldberst, 2017; Karmi, 2001; Yaar \& Eitan, 2016). The concepts of "neighborhood" and "neighboring unit" were highly used in

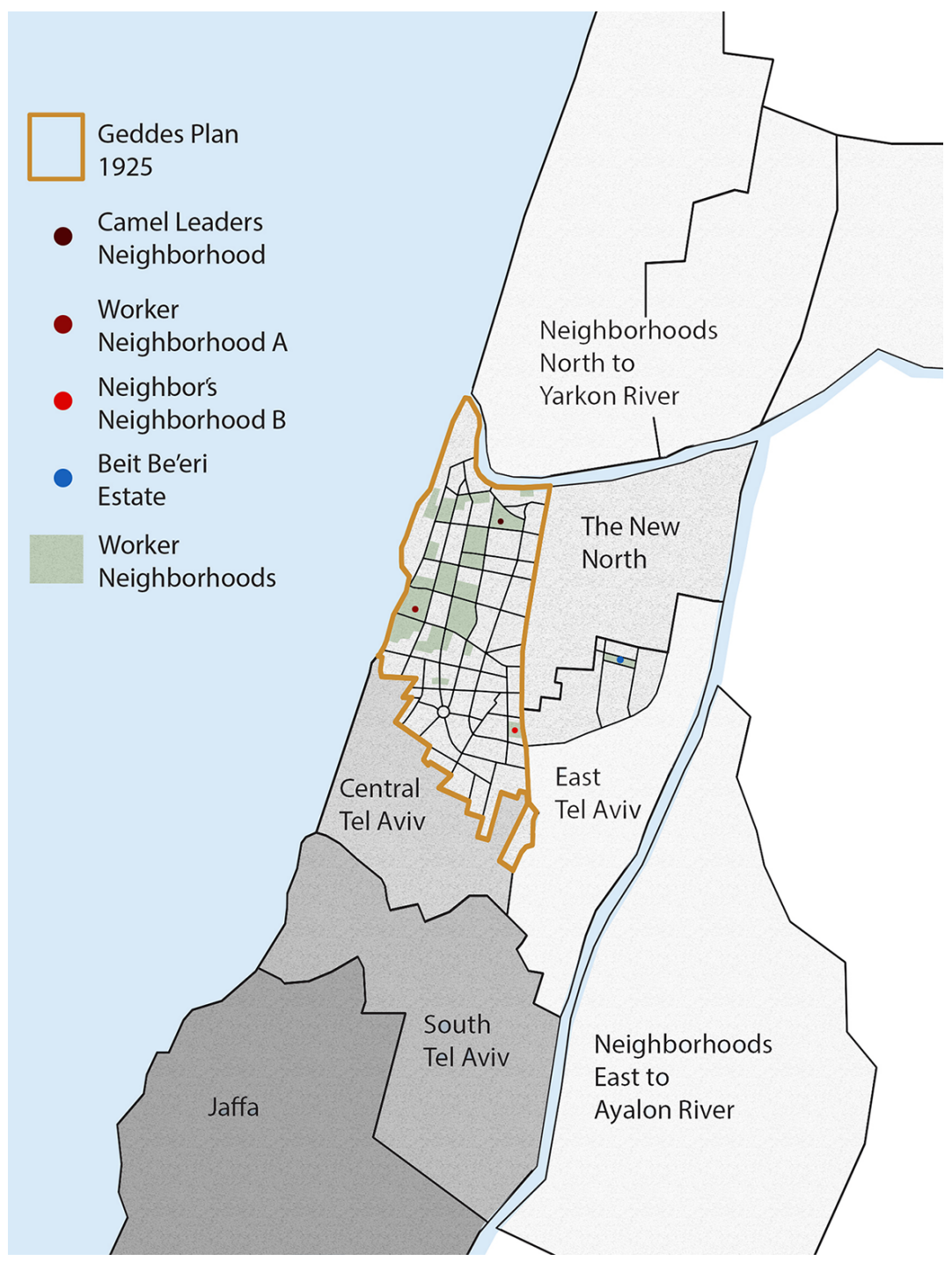

Figure 8. Scheme after Geddes' plan area within contemporary Tel Aviv-Jaffa area, with the location of Worker Neighborhood A, Neighbors' Neighborhood B, Camel Leaders Neighborhood and Be'eri Estate. Source: Authors. 
the planning professional discourse in Israel. Often discussed revolving post-war new towns in Israel's periphery (Shadar, 2014), little attention is given to the significance of these planning concepts to the extension of housing-based urbanism in Tel Aviv beyond the scope of the Geddes plan area. Scant research of Israeli Brutalist housing estates revolves around estates developed in Tel Aviv, incorporated as home-blocks in the East and North of the Geddes plan area, as part of the city's post-war expansion (Hoffmann \& Nevo-Goldberst, 2017; Marom, 2009).

Seeking an architectural language to express local culture, post-war architects referenced Geddes' architectural legacy, addressing the Geddesian grid and homeblock urban unit as a local historical planning approach (Hoffmann \& Nevo-Goldberst, 2017; Yaar, 2016). This process involved the development of neighborhoods as groups of dwellings and communal open spaces that en- courage humane interactions and establish local communities (Shadar, 2013), echoing Geddes' critique of modern urban planning yet based on higher dwelling density (Boyer, 2017; Shadar, Orr, \& Maizel, 2011; Team X, 1968; Van den Heuvel \& Risselada, 2005).

Beit Be'eri, a cooperative housing estate, exemplifies extra-large housing built in the eastern edge of Tel Aviv in 1965, on Sarona lands incorporated into the city in the 1950s (Marom, 2009). The estate consists of 192 units in two horizontal blocks and two towers, four parks, parking and a service road, totaling 13 square kilometers (see Figures 9, 10 and 11). Several of Israel's prominent architects-Sharon, Karmi, Idelson, Melzer, Zur, and Yahalom-collaborated in designing the estate as an urban matter (Hoffmann \& Nevo-Goldberst, 2017). The architects' team designed the estate on the entire urban block defined by the city's streets and hospital complex. By utilizing the extra-large plot and forming a compre-

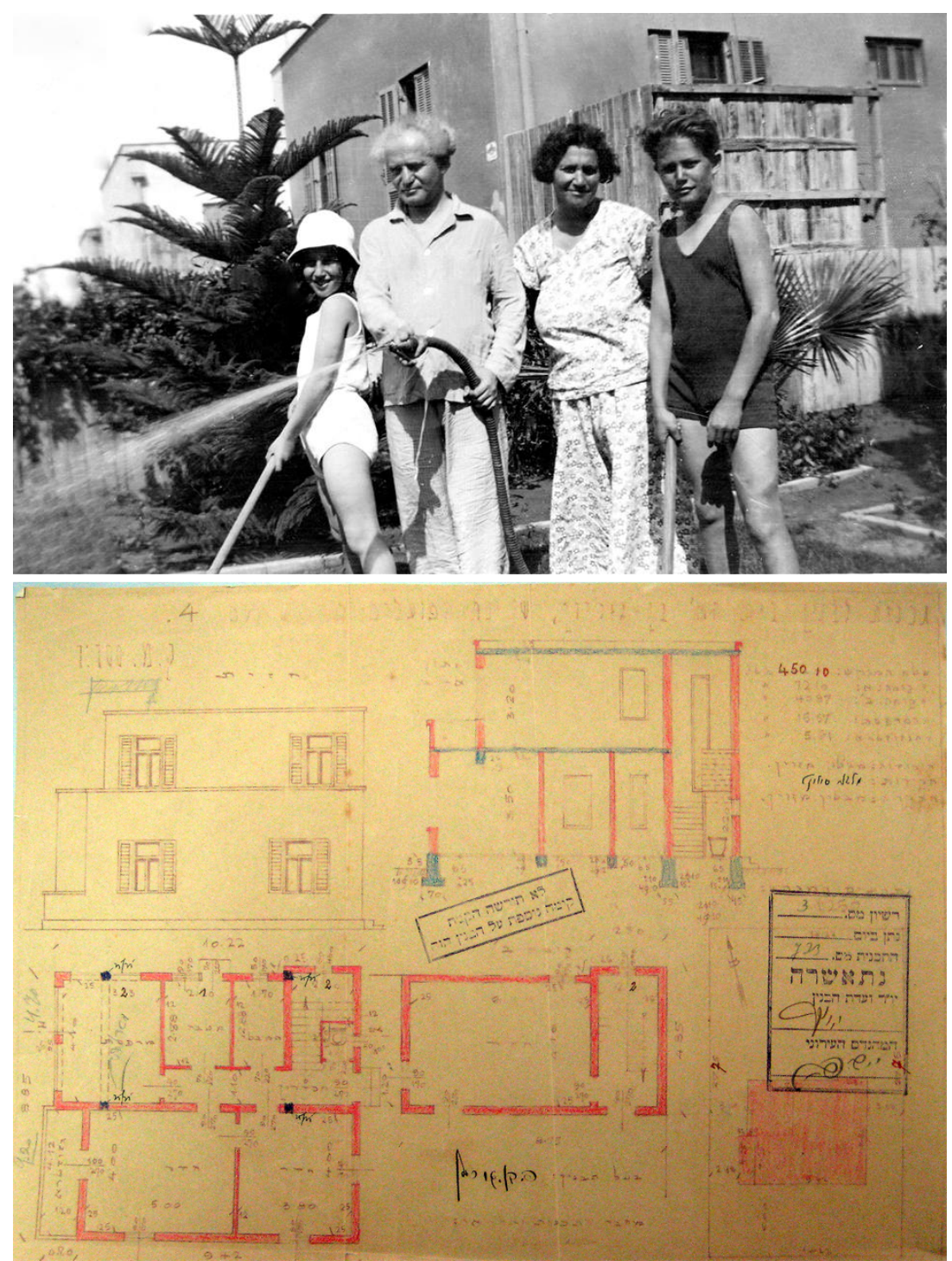

Figure 9. Workers' Neighborhood A. Top: Ben Gurion family in front of their house, Worker Neighborhood A, 1935 (Aner, 1988). Bottom: Building permit for the house of David Ben-Gurion, Municipal Worker Neighborhood plot number 4 ("Building permit for the house of David Ben-Gurion", 1931). 


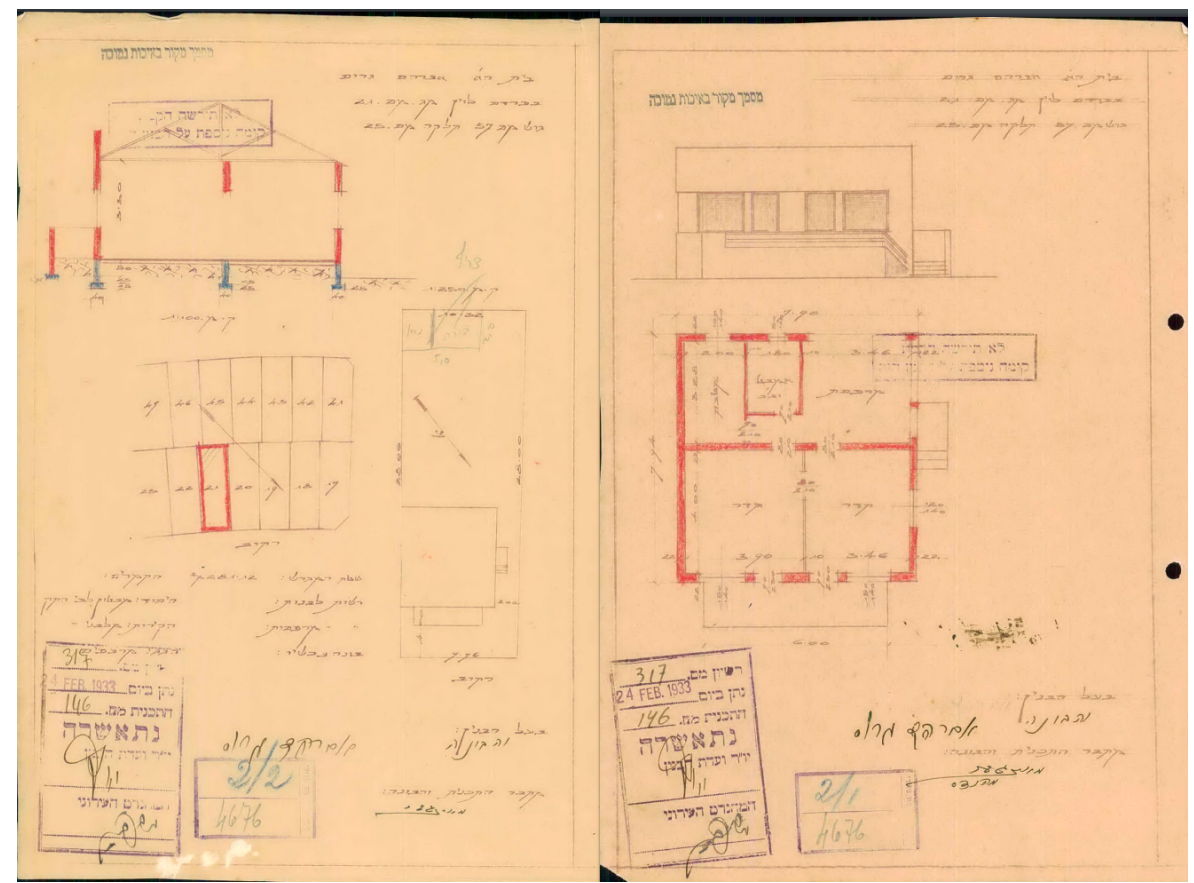

Figure 10. Building permit for the house of Abraham Gross, Levin Orchard plot number 21. Source: "Building permit for the house of Abraham Gross", 1933.

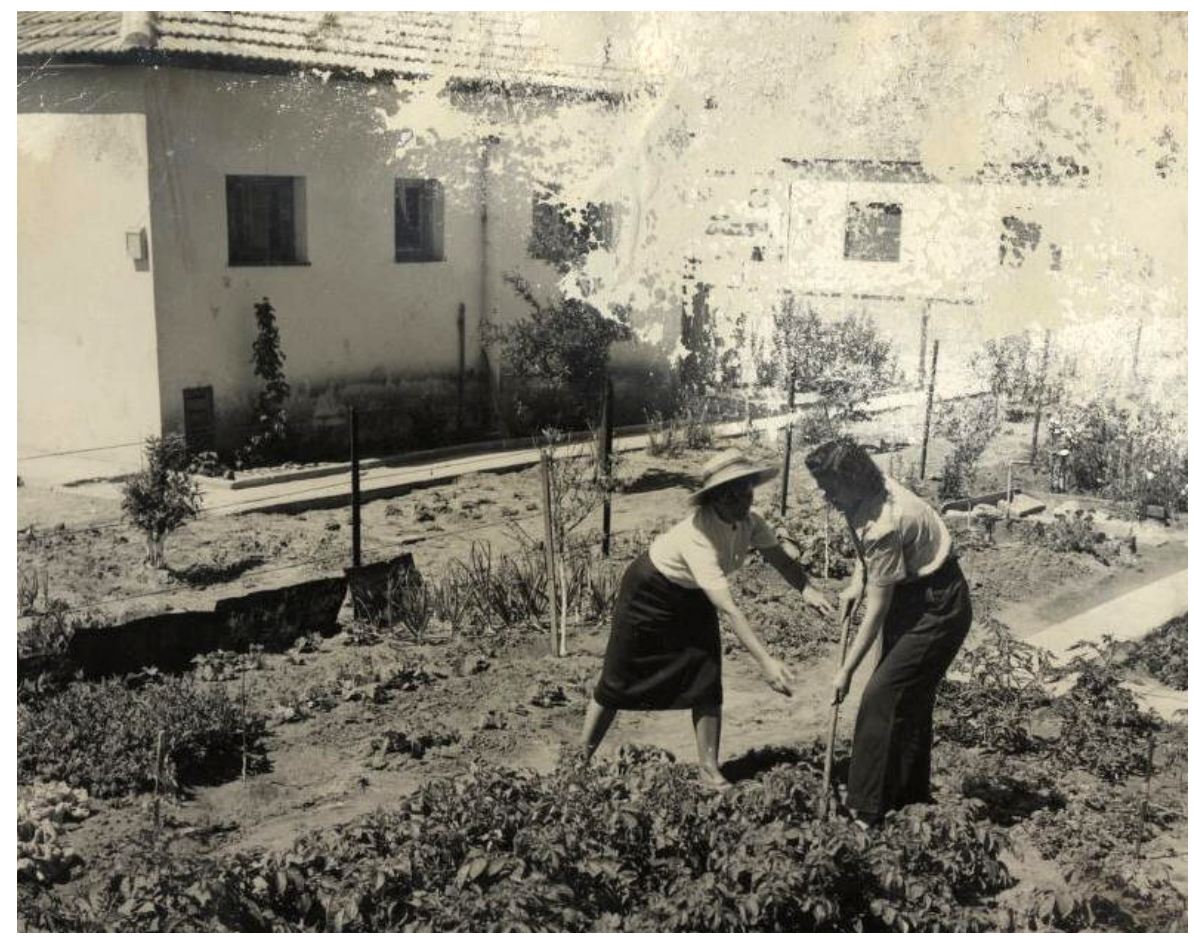

Figure 11. Neighbors' Neighborhood C. Source: Unknown [ca. 1934].

hensive architectural group, they aimed to critically oppose the gradual break down of the city's home-block urban layout-an outcome of a market-led process, replacing the Geddesian cottages with multi-story apartment houses.

The architects indicated their aim to plan the city as a 'big house' (Team X, 1968) by designing urban layout and urban housing as one single problem and de- signing what they defined as "bigger projects" in central Tel Aviv (Sharon \& Karmi, 1960, p. 3). They therefore designed an entire urban block as one comprehensive home-block, rather than an assembly of selfstanding multi-story apartment houses. Evidently echoing the Brutalist estates of the time-as well as the work of Clarence, Stein, and Mumford in such Garden City estates as Sunnyside Gardens in New York City-the estate 
embeds Geddes' idea of urban development by way of residential semi-autonomous home-blocks, rather than industry, commerce or governance structures (Karmi, 1965; Mumford, 1925, 1995; Team X, 1968). Be'eri estate won the Rokah Award for architecture, awarded by the City of Tel Aviv in 1970, in recognition of its contribution to the city's development. The award stated that the estate's planners explicitly approached "the problem of an urban housing scheme" by relating "the overall form of the complex (estate) to the scale and character of the city, while at the same time creating a more intimate environment appropriate for the individuals...living within the boundaries of the site" (Gilbert, 1970, p. 1).

\section{The City as Social Utility for Reform and Reconstruction}

For Geddes, social reconstruction consisted of the efforts of millions of individuals in the "creation, city by city, region by region, of a utopia" (Geddes, 1912, p. 183), rather than sweeping governmental measures like the abolition of private property. Geddes agreed with Reclus and Kropotkin, who in turn were influenced by Proudhon and Bakunin, regarding individual property ownership as the essential guarantee of a free society, providing the basis for a decentralized, non-hierarchical system of governance (Proudhon, 1969). Housing was, for Geddes, the basic grounds for social reconstruction using associations and guilds: the educational program, the public open spaces committee, and significantly the Housing Guild. The Social Union's Housing Guild Geddes initiated in Edinburgh set up a fund by managing property for owners and organizing rent collection by volunteers. This idea was developed during Geddes' visits to India, starting in 1914, where he developed 24 planning reports for 24 different cities. Critiquing the British administration's fixation on sanitation and racial segregation to prevent disease, and fraught planning methods ranging from the Haussmanian opening of vast roads by clearing parts of the densely populated Indian city to water closets that cost twice as the value of the houses. Geddes thereby critiques the modern colonial planning mechanism altogether: assumptions, methods, goals, and knowhow (Tyrwhitt \& Geddes, 1947).

Geddes' idea that cities should be built and governed by their poor dwellers-and that there can, and should, be planning for this purpose-was far more radical than his idea of the city in the region, identifying the question of housing (rather than commerce or industry) as central to the very aims and idea of planned settlements, their raison-d'être as well as economic bases and formative mechanism (Mumford, as cited in Howard \& Osborn, 1946). While social reform activists and planners proposed housing solutions for and on behalf of the poor via top-down schemes, Geddes' approach to urban housing was termed by Hall a "city of sweat equity", namely "contributing to planning theory the idea that men and women could make their own cities" and the idea of the role of planning in leading a civic reconstitution of society and cities (Hall, 1988, p. 263). Comparing Geddes' ideas for city planning with Howard's Garden City, we see they are strikingly different in the role assigned to the people's own actions in construction of their homes and the city, the latter model based on purchase of cheap farm land by industrialists as investment in a city of good worker housing to be paid back as rent and property values go up. It was planned for and on behalf of the workers, using industrialist entrepreneurial money for philanthropic social reform. This "peaceful path for real reform", as the subtitle of the first edition of Howard's Garden Cities of Tomorrow, was a pacifying attempt to avoid revolutionary reform by planning good worker housing in better cities (with a backdrop of worker attempts to take the city in the 1878 Paris commune, and later the 1905 Russian revolution). Geddes' planning strategy disrupts the dichotomy taken for granted by modern urban planning, between the planned city produced by professional experts and governing institutions and the unplanned city produced by poor dwellers, primarily due to industrialization and urban migration. Needless to say, Geddes' ideas and design proposals for local populations were met with impatience and anger among British planners (Hussey, 1953).

The design and approval of Geddes' Tel Aviv masterplan occurred at a period of great conflict between workers and capitalists in Tel Aviv against a backdrop of grave housing conditions. Rental costs ranged forty to $50 \%$ of a worker's average wage in the early 1930s (Lavon, 1974). Tel Aviv's ordinances made only homeowners eligible to vote for municipal government, leaving workers with little representation as mere tenants of the city (Greicer, 2017). The political conflict between workers and capitalists in Tel Aviv reached a climax during the Geddes plan approval process with Mayor Dizengoff's resignation in December 1925. Tel Aviv's iconic mayor represented the city's homeowners and developers, with agendas of property-based urban citizenship and concentric land development for maximizing profit (Greicer, 2017; Marom, 2009). The workers' party, headed by the new mayor, David Bloch, held power between 1925 and 1928 at the crucial moment of British Mandate approval of Geddes' plan (Marom, 2009). Worker leadership realized the immense consequences of the plan for their struggle over the production of the city in terms of provisional access to housing as well as the political consequences of homeownership (Allweil, 2016; Greicer, 2017; Lefebvre, 1991). The direct relation between housing and urban political citizenship marked the masterplan central for workers' struggle over the production of the city in terms of access to housing.

Workers responded by unionizing into cooperatives in order to obtain loans for land purchase and construction, cooperatives similar to Tel Aviv's homebuilders' association model (Lavon, 1974). Urban workers could only afford cheap land at the edge of the Geddes plan area, far from the city center. Approving leapfrog development, 
the worker-led urban government permitted development of small self-built home-blocks at the edge of the plan area, before the infrastructure development of the Geddes plan layout: roads, electricity, water, and sewage. Following construction of worker housing, mayor Bloch's working-class administration used public funds to service these remote worker neighborhoods with roads and public services, thereby creating the Geddes Tel Aviv plan layout in a "housing before street" framework (Druyanov, 1936). Housing construction at the edges of the plan was therefore the decisive act in forming the infrastructure and layout of the Geddes plan. By 1937, there were sixteen worker neighborhoods in the Geddes plan area, marking the entire area a "worker's quarter" (Allweil, 2017; see Figure 8). Some of the original buildings still exist, standing as a testament to the existence of a workers' neighborhood with subsistence farms in what is now the heart of the city.

The Worker Neighborhood, unlike the Me'onot Ovdim (worker residence) model, declared itself an urban unit and a means for urban workers to become proper urban citizens of Tel Aviv. The first home-block, "Workers' Neighborhood A" (1930-1931) was formed by collective purchase of a cheap three-hectare plot at the northern tip of the Geddes plan area, un-serviced and far from the city center at a period of ethno-national violence. Findings at the Tel Aviv Municipal Archive indicate that engineer David Tobia designed the neighborhood layout and its 35 identical houses, each with a subsistence farm, on 0.05-hectare plots. Houses included two rooms, a porch, a kitchen, and a bathroom (see Figure 12). Poorer workers of the Camel Leaders Neighborhood first built wooden shacks for themselves and only in the late 1930s gradually began issuing building permits for the construction of small permanent houses. While meagre, the houses enabled dwellers of the city's shack neighborhoods to gain access to proper permanent housing and subsistence farms, and transformed workers into homeowners and therefore proper citizens of the city (Gur, 1992; see Figure 13). White-collar urban workers, who could afford tenementapartments, also chose the self-help management of the home-block, forming such neighborhoods as Neighbors' Neighborhood A, B and C (see Figure 14). Geddes' complete blurring of the top-down bottom-up, plannersideologues versus infill-citizenry has in fact contributed to the realization of his plan in full. It is the only example worldwide. This idea-refusing a total-control plan-

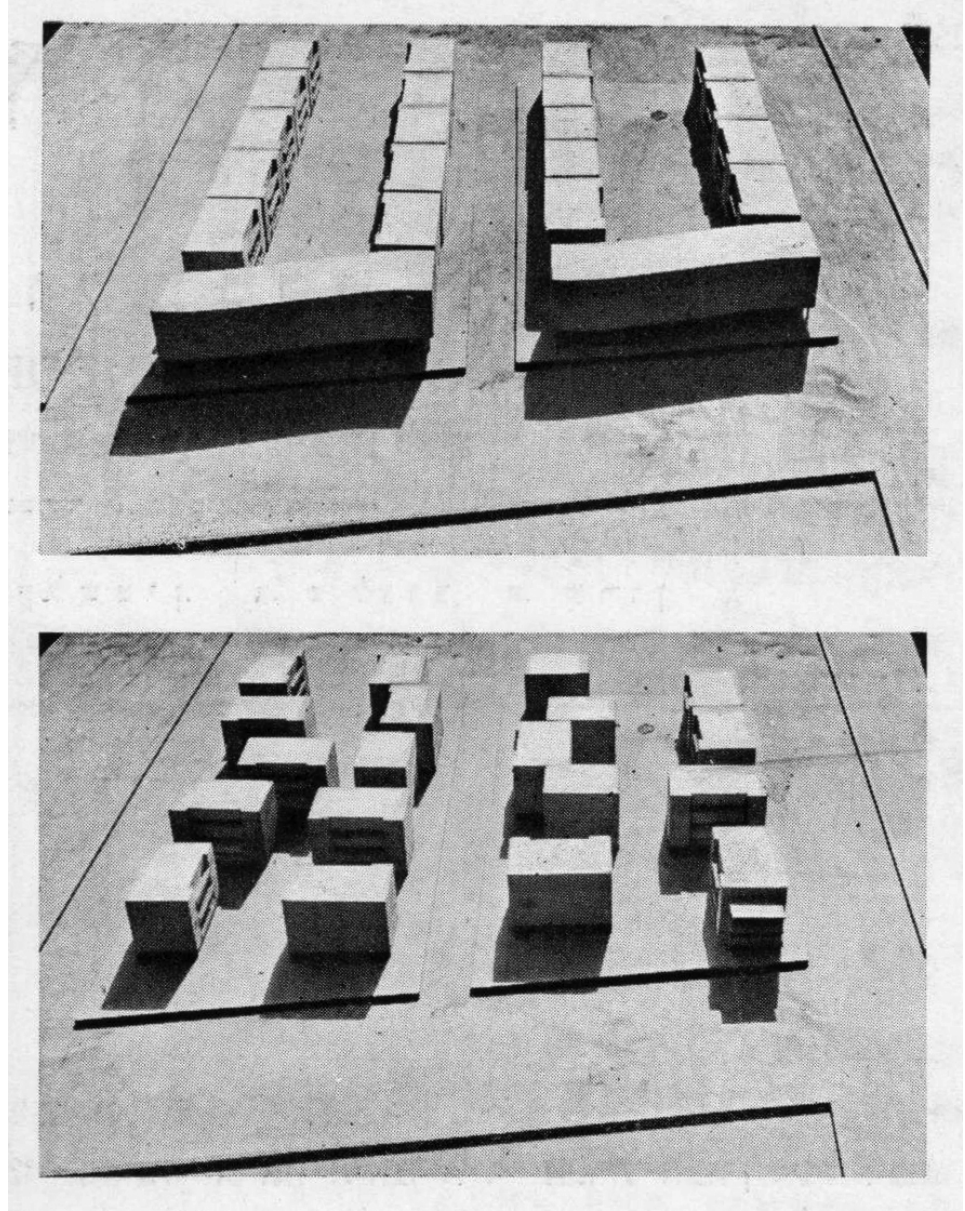

Figure 12. Arie Sharon's proposal for Me'Onot Ovdim (worker residence) in response to Tel Aviv home-block densification, 1937. Source: Sharon (1937). 


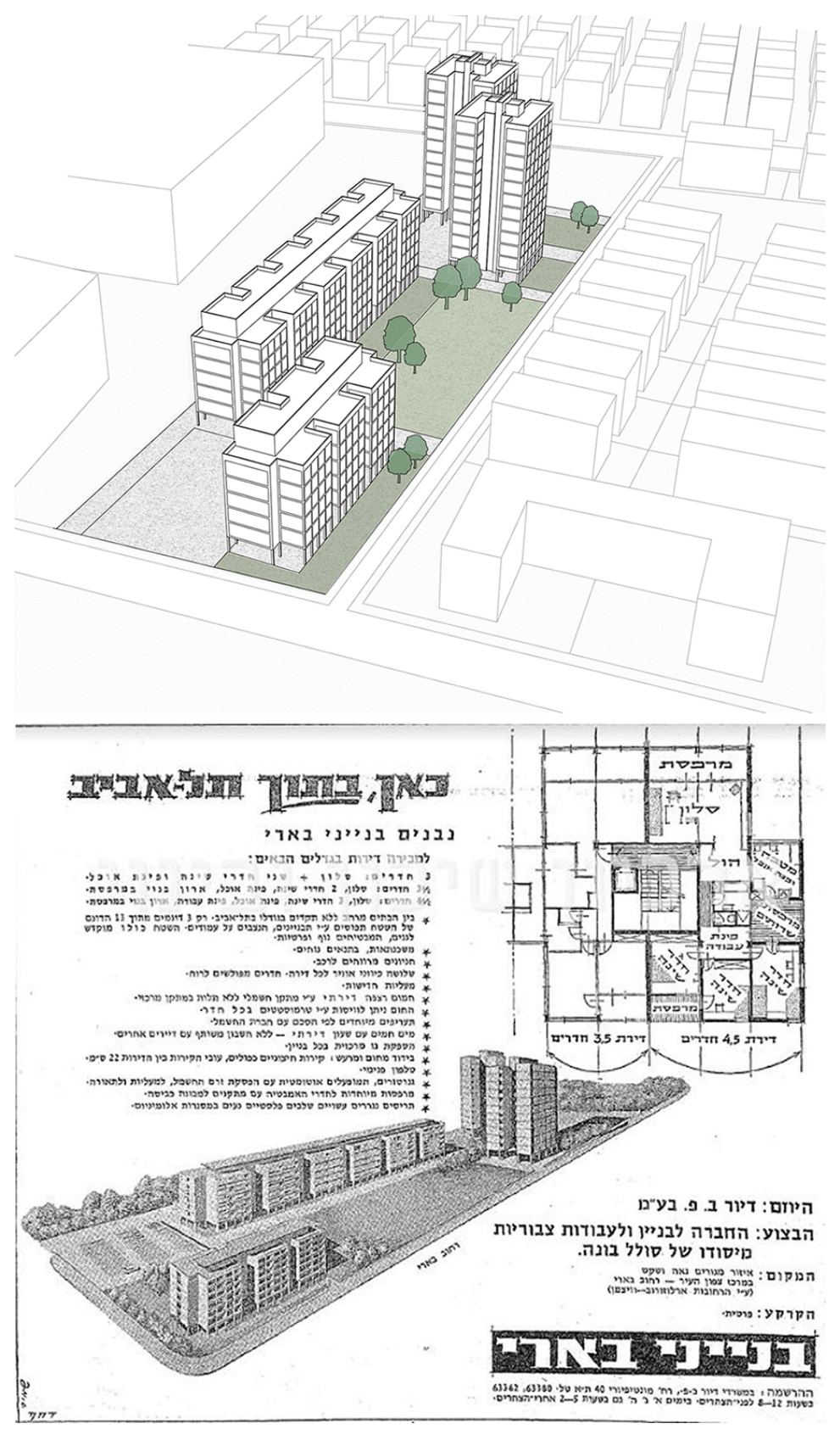

Figure 13. Be'eri estate. Top: Scheme by the authors. Bottom: Advertisement for the estate from 1963. Source: “Be'eri Dwellings", 1963.

ning that "knows best" and incorporating what residents of this specific city viewed as their self-defined goalenabled dwellers to form Tel Aviv as a "city of sweat equity" (see Figure 13).

With immigration and real estate pressures in the 1940 s and 1950s many home-block houses were gradually replaced with multi-story apartment houses, what Geddes termed "warehousing", and the home-block as an urban unit lost many of its communal characters (Karmi, 1946; Sharon, 1937). Karmi criticized post-war Tel Aviv's market-led development as a monotonous network of repetitive buildings, standing closely one to each other-forming insufficient open spaces and provoking poor neighboring relations. Subsequently, he suggested re-thinking existing city by-laws-assembling several adjacent plots and providing residents with wider communal spaces - thus improving social and environmental conditions (Karmi, 1946; see Figure 15).

Beit Be'eri designers explicitly responded to this process by producing a new model of urban home-block that enables the urban density levels required in Tel Aviv, yet providing the home-block collective infrastructure of shared parks, pedestrian walkways, and roof terraces that foster Geddes' original principles. Be'eri designers Sharon and Ram Karmi, who both served in key positions in the Ministry of Housing, along with Be'eri designer Dov Karmi and landscape architects Yahalom and Zur, expressed their ideas about the city as an essential 


\section{COGITATIO}

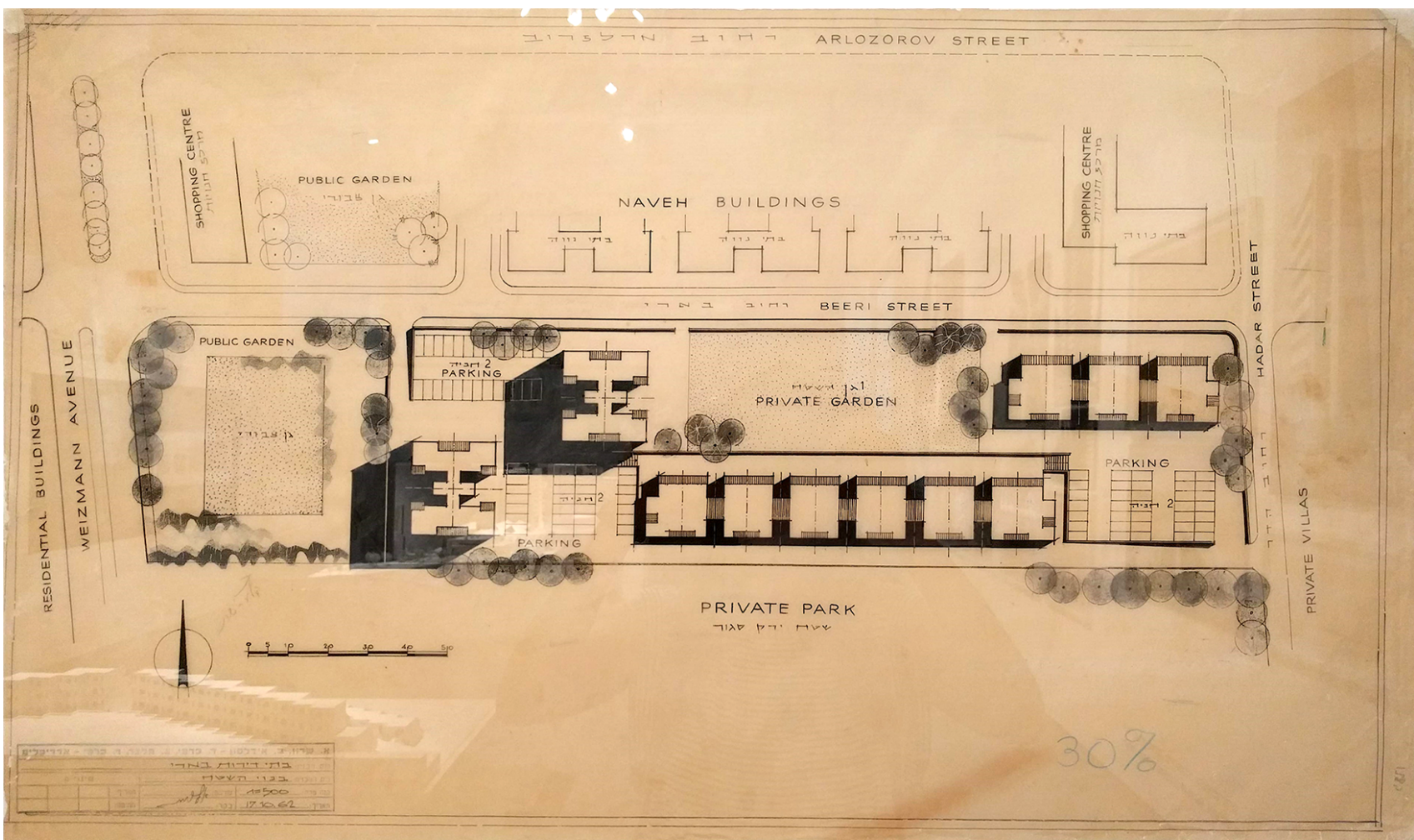

Figure 14. Be'eri estate. Source: Sharon (1962).

A 'Big House' of Two Towers and

Two Horizontal

Blocks with

Shared Teraces

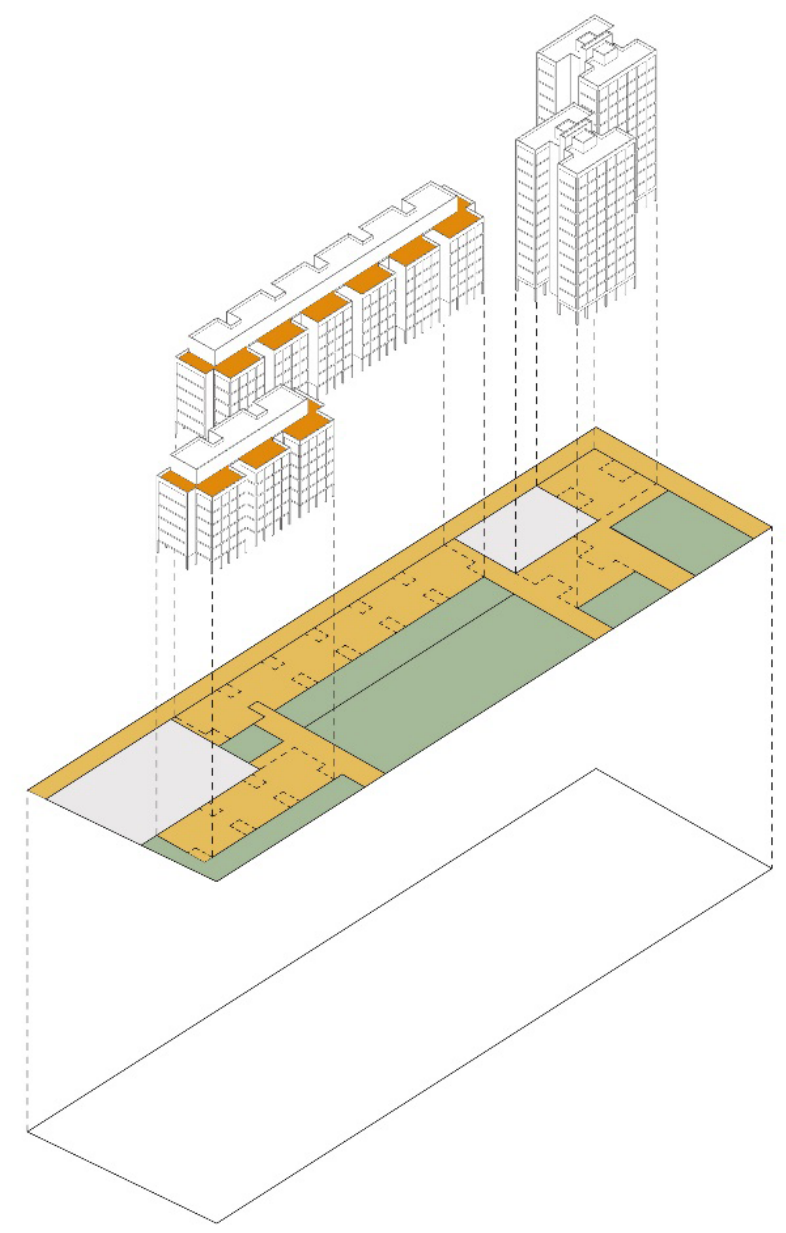

Figure 15. Be'eri estate home-block. Source: Authors. 
arena for humane interaction, and approach to architecture as a tool to consolidate functioning communities (Hoffmann \& Nevo-Goldberst, 2017; Karmi, 1946, 1965; Lissovsky \& Dolev, 2012; Sharon, 1937). Be'eri's outstanding cohort of leading designers addressed Tel Aviv's social deficiencies as a housing problem, by designing Be'eri estate as a "big house" and envisioning the city as an assembly of home-blocks. The Be'eri approach extends Sharon's critique of the densification of Geddes' homeblock, and proposals for dense worker housing on undivided home-block urban units to provide broad communal spaces, thus improving inter-neighbor interactions (Sharon, 1937). At the same time, this approach echoed Team X's Geddes-inspired critique of CIAM modernism at the 1953 and 1956 meetings on habitat and the Team X Primer, reflected in Ram Karmi's (1965) call to plan "the city as a big house, the house as a small city" (Team X, 1968, p. 27).

Be'eri's urban block meshes Geddes' home-block principles with brutalist housing architecture. The planning team decided not to subdivide the large plot but to maintain one self-managed community, a "big house" as an urban unit of the city. Planning Beit Be'eri on an area equivalent to twenty-four typical city plots and creating comprehensive communal spaces enabled them to realize, and to further, develop their social objectives of housing and open space organically-designing buildings and gardens together as holistic urban entitiesthus emphasizing communal space's importance in promoting humane interaction. Beit Be'eri is therefore both an extra-large collective house and an urban block in the framework of Geddes' home-block masterplan, based on housing as the city's urban cell. With its two explicit references being the Geddesian home-block and Team X's neighborhood unit, the Be'eri estate responded to the twin challenges of housing density and the homeblock as social utility fostering urban reconstruction (see Figures 9, 10 and 11).

\section{Housing-Based Urbanization as Self-Help}

In his report for Indore, Geddes argued that British topdown planning schemes should be replaced with actions made by the residents themselves, via actions of selfhousing. For Geddes, "simplifying the building itself, to a reasonable minimum to start with, yet with incentive to improvement [using temporary materials for labor] can often, at least partly be given by the worker himself" (Geddes, 1918). The whole plan, he stressed, "must be realized with the real and active participation" of the citizens, warning against the "dangers of Municipal Government from above" resulting in "detachment from public and popular feeling and consequently...from public and popular needs and usefulness" (Geddes, 1918, pp. 70, 104).

Geddes' definition of good housing in the homeblock befitted Tel Aviv's urban workers: Restrictions on housing size and height made self-construction a real- istic possibility, and construction limited to a third of the plot met the workers' need to maintain small subsistence farms to provide at times of unemployment ("Building permit for the house of Abraham Gross", 1933). Moreover, the leapfrogging approved by Bloch's administration allowed development of cheap land at the edge of the plan for small self-built workers' housing in the home-block framework (Bloch, 1927).

Worker Neighborhood A (1930-1931) was the first worker neighborhood, involving collective organization for purchase of a three-hectare plot disconnected from the city, by the contaminated seashore ternary, considered dangerous at the time of violent clashes between Jews and Arabs (breaking out in 1929 and culminating in the 1936 Arab Revolt). Land purchase and house construction were financed by a loan from Bank Ha-Poalim (workers' bank), founded as a collective self-help institution within the General Federation of Workers in the Land of Israel, the Histadrut ("Building permit for the house of David Ben-Gurion”, 1931; Greicer, 2017; Lavon, 1974;). Worker Neighborhood A residents included the elite of worker leaders, in the first place David BenGurion, Secretary of the Histudrut and later on Israel's first prime minister. The neighborhood layout and 35 identical houses were designed by engineer Tobia in functional minimalism (Aner, 1988). Each one-bedroom house contained a living room, a kitchen, a bathroom, and a backyard sized two thirds of the plot used for vegetable garden and workshop. Tobia's design divided the worker house in three separate areas: the living area and bedroom at the front of the house, and a service area of kitchen, bathroom, and porch, facing the yard and subsistence farm ("Building permit for the house of David Ben-Gurion”, 1931; see Figure 12). Due to Ben-Gurion's public position he was granted a permit for an additional room on the roof for library and study, accessed by stairs from the main entrance, which served Ben-Gurion for his public and political activity.

The much poorer Camel Drivers' Neighborhood resulted from the unionization of camel drivers in 1932 to obtain a loan for land purchase from the Histadrut housing company (Shikun) against their future earnings (Greicer, 2017). The camel drivers' meagre means sufficed to buy the Levin Grove by the Yarkon River, on the northeast edge of the Geddes plan area. They divided up standard 0.056-hectare plots to construct two attached units, each on 0.028 hectares. These 32 square meters houses had two rooms, a kitchen, and a washroom. All structures were built by the residents themselves, as indicated in reports of the municipal technical department which inspected construction to ensure that it met minimal standards. Inspectors reported that some of the houses used scrap metal for reinforcement rather than construction-quality materials (Figure 13). As a result, the municipal technical department specifically banned construction above one floor in this neighborhood ("Building permit for the house of Abraham Gross", 1933). The backyard served families for subsistence farm- 
ing, and many contained workshops and chicken coops (Tene, 2013).

Alongside collectivist worker neighborhoods like Worker Neighborhood A and Camel Drivers' Neighborhood, four neighbors' neighborhoods were founded by white-collar workers as Neighbors' Nationhood. Their higher socio-economic status afforded them land closer to the city center, which was safer and closer to services such as schools and employment. Residents nevertheless identified themselves as workers and chose to construct home-block houses on their plots rather than three-floor apartment houses which they could let for profit. These residents demonstrated their worker identity and socialist politics by rejecting use of land and housing as means of production and transferring title to their plots to the Jewish National Fund (Greicer \& Gonen, 2009). Neighbors' Neighborhood B, on the eastern edge of the Geddes plan area, had houses with three bedrooms, a living room, a kitchen, and separate rooms for toilet and washroom. Back yards included vegetable gardens, chicken coops, and workshops. The house at 4 Latrice Street, still standing on the inner ring of a homeblock facing Gan Ha'em inner park attests that homeblock housing was realized across the Geddes plan area, even where land values were high, rather than rejected by Tel Avivians ("Building permit for the house of Yehuda Levi", 1935). Development of home-blocks so close to the city center attests to Geddes' housing-based urbanism as a political act of worker self-help and right to the city in Tel Aviv's modern development (Figure 14).

Realizing the Geddes plan in Tel Aviv was significantly the result of "sweat equity" actions of its working class, self-constructing the home-block, and thereby extending plan layout throughout the planed area, in a housing-before-street development. Geddes" "sweat equity" modern planning was deeply invested in concrete housing solutions, including the question of housing as central to the very aims and idea of planned settlements. Tel Aviv's 1925 plan was the result of conscious, anarchist planning processes where Geddes fully realized his ideas, not merely challenging top-down mechanisms but disrupting the very dichotomous perspective of modern urbanism as a clash between top-down plannersideologues and bottom-up urban citizens.

These forms of housing were largely forgotten in the city's urban history. Scholars claim that the home-block was realized in layout alone, while house units were built in the 1930s by Bauhaus-educated architects as multistory a partment houses, what Geddes termed warehousing (Meller, 1990; Sharon, 1937; Weill-Rochant, 2003). In response, Sharon proposed the Me'onot Ovdim (worker residence) type, based on cooperative ownership of the entire block and the design of "finger" blocks influenced primarily by German Siedlungen, which remains the only form of worker housing in Tel Aviv in mainstream historiography (Greicer, 2017; Weill-Rochant, 2003; see Figure 12). Nonetheless, examining the historical development of the Geddes area closely, findings indicate that
Geddes' housing scheme was materialized en masse in the 1930s. Moreover, the significance of these houses as urban building blocks revolved around home-block construction before urban infrastructure and urban layoutnamely, in an opposite process of urban development to that the one offered by CIAM and applied by most modern urban plans. Home-block housing in the Geddes plan area was formed by workers before the plan's layout reached them, forcing the city to extend Geddes' layout and materialize his full urban vision in a relatively short period (Allweil, 2016; Biger \& Shavit, 2001).

The planning of Be'eri estate as a cooperative housing estate of 192 units, legally registered as a single shared-house under the Israeli shared-houses law, was an explicit design decision intended for fostering a selfmanaging community in the estate. The estate has been self-managed in the past sixty years by a three-tier elected body of elected residents who represent the interests of each entry within the blocks, each block/tower, and the home-block at large vis-à-vis neighboring urban blocks and the adjacent hospital. The Be'eri home-block structure provides the built framework for a community in constant negotiations over the uses of the four parks, homeways, and other shared spaces. Constructed by Solel Boneh-a semi-public construction company part of the worker Histadrut-rather than by its own residents, the dense Brutalist estate has proved the sharedownership of the "big house" to be fertile ground for the residents to carry out actions of self-help vis-à-vis their community members as well as the city. As members of the "big house", each member of the community of 192 households has a hold on an area as large as an urban block. Residents therefore have stakes in the use, design, and future planning of the estate itself, as well as the built environment surrounding the block. Within the block, continuous negotiations over everyday use, alterations and management, run by elected representatives, shape the estate. Further, collective ownership of the urban block allows the residents to organize as a political community and voice their concerns and objections to changes to urban landscape of the city.

The Be'eri Brutalist design agenda-focused towards resident self-management of housing, inspired by Geddes and explicitly critiquing CIAM modern planning (Team X, 1968)-is also a continuation of Tel Aviv's 1925 Geddes masterplan, premised on self-autonomous home-block urban units, sustaining the high housing density required in the city (Karmi, 1965; Sharon, 1937). Be'eri planners designed the estate's facades and landscape partly left open to resident interpretation. The landscape design consists of several concrete-made surfaces, framing a series of gardens, each garden attached to each estate's building. The series of differently self-designed gardens demonstrate residents' ability to spatially-dominate their surroundings, determining communal space usage and controlling the entrance to the estate gardens (Figures 14 and 15). Beit Be'eri's architectural design, complementing its cooperative manage- 
ment, enables and promotes resident bottom-up actions as a means of self-help.

\section{Conclusion}

Pointing to the centrality of housing-based urbanism in Geddes' planning theory, manifest throughout Geddes' oeuvre, this article proposes housing builds cities as a central theme in the history of modern planning. Unravelling Geddes' housing-based urbanism in Geddes' archival material, published work, and planning proposals for cities in the UK, India and Palestine, this article proposes rethinking the history and theory of modern urban planning towards a "housing builds cities" planning agenda.

Focusing on Geddes' housing-based urbanism as the formative mechanism of Tel Aviv's celebrated modern urbanism, this article exposes the relationship between housing and modern urban planning in Geddes' only realized plan. Unlike cities planned by such forces as government, for-profit capital or philanthropy, Tel Aviv's urbanism was formed by its urban workers as a tool for self-help and social reconstruction. They produced a metropolis whose premise is dwelling rather than industry, commerce, governance, or social engineering. As shown here, Tel Aviv's housing-based urban planning was developed through negotiations among its dwellers rather than imposed by planners-ideologues. Exposing the extent of home-block construction in the early 1930s and its role in Geddes' sole realized plan, this research not only contributes to Tel Aviv's urban historiography but also to display the significance of housing for the very principles of Geddes' visionary urbanism, as well as of Tel Aviv's urban legacy. The continued legacy of Geddes' housing-based urbanism in Tel Aviv's post-war and post-independence development in Brutalist homeblocks challenges CIAM conceptions of modern planning by which housing is subject to urban layout and transportation schemes, rather than infill for top-down newtown schemata and design.

Housing based urbanism corresponds to the basic premise of planned settlements by the city planning movement in response to dire dwelling conditions of the industrial city. This article calls for reconsidering the historiography of modern urban planning beyond this city, reassessment of the history and theory of modern planning, and reconsideration of contemporary planning agenda vis-à-vis the global housing crisis.

\section{Acknowledgments}

Publication of this article was supported by the Technion Social Hub and by the Technion Center for Urban and Regional Studies (CURS).

\section{Conflict of Interests}

The authors declare no conflict of interests.

\section{References}

Allweil, Y. (2016). Anarchist city? Sir Patrick Geddes' housing-based plan for Tel Aviv, and the housing protests of 2011. In R. J. White, S. Springer, \& M. L. de Souza (Eds.), The practice of freedom: Anarchism, geography, and the spirit of revolt (pp. 43-63). Lanham, MD: Rowman \& Littlefield.

Allweil, Y. (2017). Homeland: Zionism as housing regime, 1860-2011. London: Routledge.

Aner, Z. (1988). House stories. Tel Aviv: Orbach Editions.

Be'eri Dwellings. (1963). [Advertisement in Davar newspaper]. Press Archive, The National Library of Israel, Jerusalem, Israel.

Biger, G., \& Shavit, J. (2001). The history of Tel Aviv, part A: From neighborhoods to city. Tel Aviv: Ramot.

Bloch, D. (1927). Installing roads for the northern neighborhoods. Mayor's files. Tel Aviv Municipal Archive, Tel Aviv, Israel.

Boardman, P. (1978). The worlds of Patrick Geddes: Biologist, town planner, re-educator, peace-warrior. London: Routledge and Kegan Paul.

Boyer, M. C. (2017). Not quite architecture: Writing around Alison and Peter Smithson. Boston, MA: MIT Press.

Building permit for the house of David Ben-Gurion, Municipal Worker Neighborhood plot number 4. (1931). Ben Gurion Boulevard no 17 file. Tel Aviv Municipal Archive, Tel Aviv, Israel.

Building permit for the house of Abraham Gross, Levin Orchard plot number 21. (1933). Yeshayahu St. no 36 file. Tel Aviv Technical Archive, Tel Aviv, Israel.

Building permit for the house of Yehuda Levi, Neighbors' Neighborhood B plot number 23. (1935). Latrice St. no 4 file. Tel Aviv Technical Archive, Tel Aviv, Israel.

Defries, A. D. (1927). The interpreter Geddes: The man and his gospel. London: Routledge.

Druyanov, A. (1936). The book of Tel Aviv. Tel Aviv: Tel Aviv Book Committee.

Geddes, P. (1912). The two-fold aspect of the industrial age. Town Planning Review, 3(3), 176.

Geddes, P. (1915). Cities in evolution: An introduction to the town planning movement and to the study of civics. London: Williams \& Norgate.

Geddes, P. (1918). Town planning towards city development: A report to the Durbar of Indore. Indore: Durbar of Indore.

Geddes, P. (1925). Town planning report: Jaffa and Tel Aviv.

Greicer, I. (2017). From a neighborhood to a housing estate. Tel Aviv: Pardes.

Greicer, I., \& Gonen, O. (2009). Design of the state's early settlement map. In M. Lissak (Ed.), Studies in Israel's social history (pp. 249-349). Jerusalem: Bialik Institute.

Gilbert, H., (1970). Rokah Prize: Judge Report. Rokah Prize File, Tel Aviv City Archive, Tel Aviv, Israel.

Gur, Y. (1992). Concepts of public housing in Israel: The 
formative years 1920-1948 (Unpublished Doctoral dissertation). Haifa: Technion University.

Hall, P. (1988). Cities of tomorrow. Berkeley, CA: University of California Press.

Hoffmann, J., \& Nevo-Goldberst, H. (2017). Aphoria: Architecture of independence, 1948-1977. Haifa: Technion Center of Built Heritage.

Howard, E., \& Osborn, F. J. (1946). Garden cities of tomorrow: With an introductory essay by Lewis Mumford. London: Faber and Faber.

Hussey, C. E. C. (1953). The life of Sir Edwin Lutyens. London: Country Life.

Karmi, D. (1946). Problems in planning apartments in Tel Aviv. Journal of The Federation of Engineers and Architects in Israel, 7, 3-4.

Karmi, R. (1965). Architecture of shade: Reflections on a new housing form in the context of a building in New Beer-Sheba Neighborhoods B and D. Kav, 3, 22-44.

Karmi, R. (2001). Lyrical architecture. Tel Aviv: Misrad Habitachon.

Lavon, Z. (1974). Shelter. Tel Aviv: Am Oved.

Law, A. (2005). The ghost of Patrick Geddes: Civics as applied sociology. Sociological Research Online, 10(2). https://doi.org/10.5153/sro.1092

Lefebvre, H. (1991). The production of space. Oxford: Wiley-Blackwell.

Leonard, S. G. (1999). The regeneration of the old town of Edinburgh by Patrick Geddes. Planning History, 21, 33-47.

Lissovsky, N., \& Dolev, D. (2012). Arcadia: The gardens of Lipa Yahalom and Dan Zur. Tel Aviv: Babel.

Marom, N. (2009). City of concept. Tel Aviv: Babel.

Meller, H. (1990). Patrick Geddes: Social evolutionist and town planner. London: Routledge.

Meller, H. (1995). Philanthropy and public enterprise: International exhibitions and the modern town planning movement, 1889-1913. Planning Perspectives, 10(3), 295-310.

Mumford, L. (1925). The regional community. The Survey, 54(3), 129.

Mumford, L. (1995). Lewis Mumford and Patrick Geddes: The correspondence. Hove: Psychology Press.

Patrick Geddes Papers. (n.d.). Collection T-GED Patrick Geddes papers. University of Strathclyde Archives. Retrieved from https://sites.google.com/a/ tlv100.net/tlv100/old_north/neighb-3

Payton, N. E. (1996). Modern architecture and traditional urbanism: Patrick Geddes and the plan for Tel Aviv. The New City, 3, 4-25.

Proudhon, P. J. (1969). Selected works. New York, NY: Doubleday.
Rubin, N. H. (2009). The changing appreciation of Patrick Geddes: A case study in planning history. Planning Perspectives, 24(3), 349-366.

Shadar, H. (2013). From forced community to individualism in public urban construction. Yunim: Multidisciplinary Studies in Israeli and Modern Jewish Society, 23, 204-232.

Shadar, H. (2014). Building blocks of public housing. Jerusalem: Ministry of Housing.

Shadar, H., Orr, Z., \& Maizel, Y. (2011). Contested homes: Professionalism, hegemony, and architecture in times of change. Space and Culture, 14(3), 269-290.

Sharon, A. (1937). Planning cooperative houses. Habinyan: Journal of Architecture and Town Planning, 1937(August), 1-4.

Sharon, A. (1962). Be'eri estate. [Architectural drawing]. Arieh Sharon Files, The David Azrieli Archive of Israeli Architecture, Tel Aviv, Israel.

Sharon, A., \& Karmi, D., (1960). Beeri Housing Tel Aviv. [Letter]. Arieh Sharon Files, The David Azrieli Archive of Israeli Architecture, Tel Aviv, Israel.

Team X. (1968). Team X primer. Boston, MA: MIT.

Tene, O. (2013). The white houses will be filled. Tel Aviv: Ha'Kibbutz Ha'Meuchad.

Tyrwhitt, J. (1949). Introduction. In P. Geddes \& O. T. Association (Eds.), Cities in evolution (pp. ix-xxviii). London: Williams \& Norgate.

Tyrwhitt, J., \& Geddes, S. P. (1947). Patrick Geddes in India. London: Lund Humphries.

Unknown. [ca. 1934]. Neighbors' neighborhood C. Tel Aviv 100 Encyclopedia. Retrieved from https:// sites.google.com/a/tlv100.net/tlv100/old_north/ neighb-3

Van den Heuvel, D., \& Risselada, M. (2005). Team 10: In search of a utopia of the present, 1953-1981. Rotterdam: NAi Publishers.

Weill-Rochant, C. (2003). Mythes et constructions de Tel Aviv [Myths and constructions of Tel Aviv]. Bulletin du Centre de Recherche Français de Jérusalem, 12, 80-96.

Weill-Rochant, C. (2008). L'atlas de Tel Aviv: 1908-2008 [The Atlas of Tel Aviv: 1908-2008]. Paris: CNRS Editions.

Welter, V. M. (2009). The 1925 master plan for Tel Aviv by Patrick Geddes. Israel Studies, 14(3), 94-119.

Yaar, Y., \& Eitan, A., (2016). Life and architecture. Haifa: Architectural and Landscape Heritage Research Center, The Faculty of Architecture and Town Planning, Technion. 


\section{About the Authors}

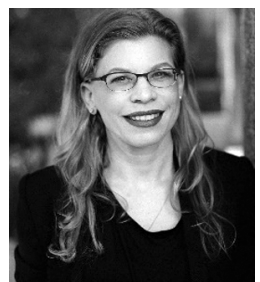

Yael Allweil (PhD) is an Architect and Assistant Professor at the Faculty of Architecture and Town Planning, at the Technion, Israel, where she heads the Housing Architecture, History and Theory research group. She completed her PhD in architecture history at UC Berkeley, exploring the history of Israel-Palestine as a history of the gain and loss of citizen housing. Her research was published in the monograph Homeland: Zionism as Housing Regime, 1860-2011 (2017, Routledge) and several journal articles in Urban Studies, Footprint, Architecture Beyond Europe, City, TDSR and IJIA.

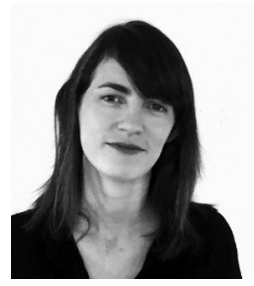

Noa Zemer is an Architect and an MSc student in the Faculty of Architecture and Town Planning at the Technion, Israel, where she is a member of the Housing Architecture, History and Theory research group. Involving her extensive practical experience in the fields of housing architecture and built heritage conservation, her research examines socio-spatial dynamics in brutalist cooperative housing. Noa's research was selected to contribute to IBA's 2019 Research Lab on New Social Housing, in Vienna. 